\title{
A Struggle for Genocide Recognition: How the Aramean, Assyrian, and Chaldean Diasporas Link Past and Present
}

\author{
Sofia Mutlu-Numansen \\ University of Twente, the Netherlands \\ Marinus Ossewaarde \\ University of Twente, the Netherlands
}

This article analyzes how Aramean, Assyrian, and Chaldean communities in Western Europe organize their struggle for Sayfo (genocide) recognition and how narratives of the past are enacted in their campaign. The year 2015 provided a unique opportunity to study such diasporic communities' strategic uses of the past. Hundreds of centenary commemorations were organized all over the world. The authors have selected three that illustrate how the Sayfo recognition campaign was organized, and how its practitioners strategically use the past in their efforts.

Since Charles Taylor's 1992 Multiculturalism and the Politics of Recognition and Axel Honneth's 1995 The Struggle for Recognition, studies of marginalized groups_including one-time victims of genocide-increasingly reflect struggles for recognition (Taylor 1992; Honneth 1995; Savage 2013; Maia 2014; MacQueen 2015). How do such groups organize to pursue recognition, and how do they enact their narratives of the past in those campaigns? Here we discuss the efforts of the Aramean, Assyrian, and Chaldean diasporic communities of the Netherlands, Germany, and Sweden toward international recognition of their experience of genocide-known as the Sayfo (from the Aramaic word for "scimitar," a weapon widely used during the genocide) — in the Ottoman Empire and Turkey during and just after the First World War. How have these communities narrated their past, and in particular memory of life in their northwest Mesopotamian homeland and the genocide of their peoples? Here we focus on how leaders and activists link a narrated past to present purposes, that is, how they use the history of the Sayfo to influence their community, both in diaspora Western Europe and elsewhere, and world opinion, with an eye to events in their ancestral Middle Eastern home (cf. Üngör 2014; Belçim Galip 2016).

Unlike the Armenian Genocide, the genocide of Arameans, Assyrians, and Chaldeans has not received much attention in either the media or scholarship. And yet the experience of these peoples was similar to that of the Armenians: all victims of central orders to destroy the entire communities (Gaunt, Atto, and Barthoma 2017). The term Sayfo appeared primarily in the oral tradition; more recently in the Aramean, Assyrian, and Chaldean diaspora activists have started using the word "genocide." The International Association of Genocide Scholars formally recognized the Sayfo as a genocide in 2007 (Gaunt, Atto, and Barthoma 2017; the Turkish government continues to deny it). Representative factors underlying recognition include the deep involvement of the civil and military commands of the Ottoman government; the enormous number of victims; the complete destruction of Assyrians in Hakkari; the special cruelty and near total destruction of the Chaldeans 
in the Anatolian province of Bitlis; and the near total destruction of the Aramean and Assyrian Syriac-Orthodox communities generally (Gaunt, Atto, and Barthoma 2017). Many Christians of all sects and ethnicities were killed during the genocide, and where only men were killed, women and children were forcibly converted to Islam. A dominant pattern seems to have been to plunder Christians' property and destroy what was immovable in order to prevent any possible return. A few successful cases of resistance were recorded, and in rare instances prominent Muslims protected Christians. In some districts in the Southeast, such as the village of Bote, more than 90 percent of the Christian population was killed. The mass extermination and ethnic cleansing of more than 500,000 Arameans, Assyrians, and Chaldeans (around 70 percent of the population if we include those lost due to flight and forced conversion) in southeastern Turkey is often simply lumped together with the deportations, mass killing, sterilizations, mutilations, and forced marriages (conversions) of Christian women during the Armenian Genocide (Gaunt 2006; Gigneras 2008; Balakian 2013; Morris and Ze'evi).

According to specialists, the ancient Arameans were nomads who invaded northern Mesopotamia and founded little states. The Aramean language is classified as a member of the northwestern branch of the Semitic languages; the, Assyrians, Chaldeans, Akkadians, and Babylonians speak eastern Semitic languages (WCA 2017). Though the Arameans and Assyrians are technically two different peoples, their Sayfo victims in Turkey regarded themselves, and were regarded by others, as one people: Syriacs (from the Syriac-Orthodox religion so intertwined with their identity). It was only after migration from Turkey in the 1970s that these Syriacs started to identify as either Arameans or Assyrians. (Even within one family, people can disagree on their identity.) The Chaldeans were also early immigrants into Mesopotamia, briefly ruled over the Babylonian Empire, and in the Byzantine Empire became Christians (currently the Chaldean Catholic Church). In recent publications "Assyrians" is often used as a generic term for Arameans, Assyrians, and Chaldeans, but the term is inaccurate because many members of these groups do not refer to themselves as Assyrians. Here we use all three terms, reflecting changes in the peoples' circumstances, differing ideas about the historical past among the same group of people, and various opinions regarding the best ethnonym to be used (Omtzigt, Tozman, and Tyndall 2012). In contrast with Greeks and Armenians, as of 1915 the Aramean, Assyrian, and Chaldean communities had had no states of their own for thousands of years.

During World War I these three inter-related communities experienced genocide at the hands of local Kurdish tribes and the Ottoman army in an ethno-religious conflict zone where KurdishIslamic locals had for some time manifested a murderous predisposition vis-à-vis Christian minorities (Melson 2013; Ümit Üngör 2014; Belçim Galip 2016). When the small number of Aramean, Assyrian, and Chaldean survivors eventually found the means to escape from Turkey during another wave of persecution in the 1970s they entered into a worldwide diaspora that included significant centers in Western Europe. In the democratic countries these communities enjoyed for the first time in their post-genocidal history the opportunity to fight for international recognition of their genocide. In 2015, the campaign reached its climax. Hundreds of Sayfo centenary commemorations were organized, including peaceful protest marches, the production of documentary films, the dedication of memorials, and so forth in Belgium, France, the Netherlands, Germany, Sweden, and elsewhere. New Sayfo organizations were founded (such as Comité 1915 in the Netherlands), and activists established new alliances with Armenian associations to facilitate joint activities for the centenary of the genocide against Christians in Turkey (Comité 1915, 2015). 
To analyze how the Aramean, Assyrian, and Chaldean communities in Western Europe organized to pursue recognition, we will discuss three case studies. In the first, we investigate the role of hierarchy and the top-down organization; in the Christian communities "hierarchy" refers first of all to the ecclesiastical hierarchy, that is, of the Syriac-Orthodox Church. We observed commemorations by the Syriac-Orthodox Church in the Netherlands in February and March 2015, and conducted a semi-structured interview (some questions planned, some spontaneous follow-up) with Metropolitan Mor Polycarpus Augin Aydin of the Syriac-Orthodox Church of the Netherlands on February 23, 2016. In our second case study we analyze a bottom-up organization of the campaign by a local Aramean-Assyrian-Chaldean committee-the Dutch and Swedish branches of the so-called "Bote Committee" (named for the village of Bote in southeastern Turkey, site of an exceptionally thorough massacre in 1915). We observed all meetings of the international Bote Committee culminating in a Sayfo commemoration in Gothenburg, Sweden, conducted semistructured interviews with five Committee members in January 2016, and held conversations with several visitors to the commemoration in Gothenburg. In our third case study we discuss the role of the World Council of Arameans (WCA). In the context of the Sayfo centenary, the WCA made a Dutch documentary, called Sayfo: The Forgotten Genocide (Evangelische Omroep 2015); broadcast on Dutch television on April 22, 2015, this documentary reflects its makers'strategic uses of the past. In May 2016 we interviewed the chairman of the WCA regarding the role of the documentary in that organization's recognition efforts.

\section{Struggles for Recognition}

Both Taylor and Honneth reconsider Hegel's original contention that self-realization depends upon the recognition we receive from others, and that therefore nation-building thus represents the progressive realization of expanded forms of recognition (MacNay 2008, 276). For Taylor (1992, 26), the struggle for recognition is the pursuit of equal cultural worth, as against secondclass citizenship. Persons or groups can suffer a real distortion of their own identity when others around them communicate a demeaning picture of them. "Non-recognition or misrecognition can inflict harm, can be a form of oppression, imprisoning someone in a false, distorted, and reduced mode of being," Taylor contends $(1992,25)$. In Taylor's work, it is new social movements (such as multiculturalism, post-colonialism, feminism, or the LGBTQ movement) that struggle for recognition. Such movements seek acceptance within a modern political landscape (post-1968) that is less defined by class than by identity differences. Taylor focuses on securing the value of collective identities as unique and irreplaceable frameworks within which individuals can generate a meaningful sense of authentic selfhood (MacQueen 2015, 21-22).

For Honneth, by contrast, the concept of "recognition struggle" has less to do with identity than with the articulation of how power is effectively enacted in people's negative experiences, such as cultural denigration, humiliation, and disrespect. For him, recognition is intrinsically connected to protecting individuals from injury, feelings of being unjustly treated, and the experience of being disrespected. In contrast with Taylor, Honneth does not employ the concept to make sense of the rise of new social movements' identity politics, but instead uses it to uncover social pathologies that impede individual self-realization (Maia 2014, 42, 51, 127; MacQueen 2015). If we go along with Honneth, the central motive for strategically mobilizing the past is to be found less in constituting a (diaspora) identity than in the painful, traumatic experience of having been violated, dominated, stigmatized, or denied human rights (cf. Presbey 2003; Kleist 2008). 
Various scholars have employed the concept of recognition struggle to make sense of the identity politics and collective self-realization of ethnic groups and diaspora communities. Bill Bowring (2002), for instance, has analyzed the Crimean Tatar and Chechen struggles for recognition in Russia-two communities with a traumatic history of oppression in the Soviet period who refused to sign the 1992 Federation Treaty that established the place of the nominally non-Russian territorial units within post-Soviet Russia. Bowring observes that the Tatar struggle for recognition has been highly successful, whereas the Chechens' has been equally unsuccessful. During the 1990s, the Tatars achieved a high degree of cultural autonomy within the Russian Federation, which enables them to express their collective identity. The Chechens, by contrast, failed to obtain such autonomy and militarized their recognition campaign. Bowring explains that the Tartars owe their success to their strategic uses of the past. Both Crimean Tatars and Chechens experienced Stalin's collective punishment (deportation from their historic home territories) in 1944 for alleged collaboration with Nazi Germany. But the Tatars (both of the Volga and the Crimea) managed to organize memory in such a way that they are recognized for a long history of loyal service to the tsar. The Chechens, by contrast, were unable to negate their popular image as Islamists, gangsters, even terrorists, and as a result their struggle for recognition was widely interpreted as lawless rebellion.

Gail Presbey (2003) has applied the concept of recognition struggle to the efforts of the Bantu tribes in South-Africa's post-apartheid order. Presbey finds that the Bantu campaign must be understood as the group's effort to be treated as the economic, political, social, and cultural equals of all other ethnic groups. Through strategic uses of the past and by promoting images of inclusion in (and contribution to) the country, Bantu communities have achieved considerable success. Such communities are encouraged and legally facilitated by the UN's 1992 Declaration on the Rights of Persons Belonging to National or Ethnic, Religious, and Linguistic Minorities (Bowring 2002).

Similarly, diasporic communities in the West have campaigned for recognition in multi-cultural host nations. When such struggles involve the recognition of past injuries or trauma, then these can be addressed "from a memorial perspective" (Gouriévidis 2014, 13). From that vantage point, the Aramean, Assyrian, and Chaldean struggle for Sayfo recognition is complicated by frequent submersion within the Armenian Genocide: this, among other factors, qualifies the Sayfo as a "forgotten genocide" (Courtois 2004; Gaunt 2006). One recalls Dirk Moses’s controversial question about whether the Holocaust reveals or conceals other genocides (Moses 2013): if the media and popular culture focus on one major event, that can draw attention to related events, but it might also distract it from them.

Moses observes that kind of irony in the Canadian government's establishment of the Commission of Inquiry on War Criminals in Canada (Deschenes Commission) in 1985. Despite efforts by Ukrainian-Canadians, the suffering of Ukrainians under Stalin was omitted because the Commission focused solely on Axis (and collaborator) crimes during the Second World War; and because it was unlikely that any useful evidence would arrive from the Soviet Union the USSR would provide evidence against Ukrainian collaborators with Nazi Germany, just not collaborators with the Stalin regime). Another example figuring in Moses treatment is that the Holocaust gets a national remembrance day in Canada, while Canada's handling of its own indigenous peoples does not. One explanation is that indigenous people do not dispose the resources-recall other immigrant-group (notably Jewish) organizations' government-liaison staff and national committees with imposing titles - to lobby for their claims. Moses notes another difference between Holocaust and Holodomor (Ukraine famine) survivors: the latter encountered particular difficulties in challenging Holodomor 
deniers; and indeed, even many sympathetic scholars do not see the Holodomor as a planned genocide but rather a horrific facet of Stalin's war to collectivize the peasantry throughout the Soviet Union.

Lobbying by the Russian Federation at the UN to ensure the Holodomor was not declared a genocide constituted another obstacle. The official Ukrainian narrative of the Holodomor as a genocide and the corresponding memory regime in Ukraine have been contested, renegotiated, and modified at the regional level, reflecting impulses from Russian majorities in some parts of the country. Geographic proximity added an international dimension, as the Holodomor issue became a stumbling block in Ukrainian-Russian relations (Zhurzhenko 2011). Russian scholars deny the famine was limited to Ukraine, and Ukrainian scholars claim the opposite. Moore (2012) notes that some urge that if the word "genocide" does not apply to Ukraine, then it loses all meaning; even he, however, stresses that the definitional parameters remain highly contested.

Similar issues emerge when we consider the Sayfo. Without a state or a large intellectual elite of their own; trapped in an authoritarian Turkey where Sayfo survivors were subject to official Turkification, assimilation, ethnic cleansing, petty persecutions, intimidation, and systematic discrimination for many decades (Levene 1998; Dixon 2010; Özlem Biner 2011; Önder 2012); the Christian minorities of the Southeast could organize no struggle for Sayfo recognition in the public domain. The lack of legal status as a recognized minority makes the feeling of oppression even worse than for Armenians. The de facto legitimacy the government enjoys through Turkey's membership in the UN, and the Erdogan government's combination of nationalism and Islamism (Melson 2013; Ümit Üngör 2014), only amplify the Christians' feelings of hopelessness.

Memory of the Sayfo has survived via oral transmission within survivors' families based on eyewitness accounts. Persecuted, the small Christian minorities could organize no efforts outside the home. As Uğur Ümit Üngör (2014, 150, 151) emphasizes, “deeply traumatized” Sayfo survivors were "terrified individuals" forced to keep "a low profile in ruined villages." They had no "chance to mourn, heal or to be memorialized within Turkey," though they did pass their traumatic memories to following generations (154). The struggle for Sayfo recognition could be organized only once Arameans, Assyrians, and Chaldeans enjoyed asylum in Western Europe starting in the 1970s and after establishment of a transnational diaspora. Some 15,000 Arameans, Assyrians, and Chaldeans live in Turkey today (most outside their historic homeland, primarily in Istanbul); approximately 300,000 live in Western Europe (Atman 2010), along with other communities elsewhere in the world. The Turkish government doesn't keep statistics because it does not recognize the three peoples as official minorities, but simply counts them as Turks (Omtzigt, Tozman, and Tyndall 2012). Our figures depend largely on church records.

More than six decades after events, recognition became publicly organizable; the depression that had lasted for decades could be turned into collective mourning (cf. Gabriel 2012). Only in the diaspora could the collective "duty to remember" (Thompson 2009; Short 2012) be performed in the public domain. The Aramean, Assyrian, and Chaldean struggle for Sayfo recognition manifested itself as an "organization of memory" (Sørensen 2014, 281). Organizations of the diaspora community shape the presentation of memory, transforming it into community property and an instrument for shaping collective identity. The Sayfo narrative, rooted in eyewitness memory (be it scattered images, fragments, or inchoate feelings) is thus mobilized strategically (Allen and Brown 2016). Sayfo stories transfer pain to new generations, motivating members of the latter to pursue recognition and to craft new strategies for doing so (Maia 2014, 131, 133). The organization of memory translates 
into a repository of symbols, legends, ceremonies, icons, memorials, museums, commemorations, anniversaries, and exhibitions (Rowlinson et al. 2010; Elgenius 2011; Robben 2012; Cutcher et al. 2016).

Images and recollections of the catastrophe of World War I make viewers witnesses; "performance" of memory allows spectators today to "relive" traumatic histories. They imply a kind of arraignment of an indifferent world. In an actual theater, cathartic responses (such as crying) permit viewers to free themselves from negative affect (grief, shame, anger ...). Catharsis dissipates trauma deriving from the Sayfo itself, its post-genocidal aftermath in Turkey, and the modern world's indifference, facilitating integration of experiences and feelings into positive action (cf. Meisiek 2004; Westwood 2004). Symbolic sites of memory too provide instruments for recognition efforts. Young addresses differences between Holocaust memorials in Germany, Poland, Israel, and the U.S., observing that only Germany and Poland have actual memory sites. In fact, in the United States the relationship of the state to this memory stirs little controversy, and in Israel less still (Young 1993). Thus one and the same genocide can be remembered differently.

In diasporic communities organizations employ memory to address present community needs. The Aramean, Assyrian, and Chaldean migrant communities use a painful history to manage a diaspora identity. The elements of the recognition campaign—remembrance, mourning, representation-inscribe and reinforce a collective identity. The ecclesiastical hierarchy (the Syriac Orthodox Church of Antioch) in particular establishes terms of recognition, mediated through a transnational diaspora identity. Organized mourning strategically reinforces a particular notion of what counts most in history, what is essential to identity, and how to promote broader recognition (Cutcher et al. 2016): representation is rooted in a Church symbolism that inheres in the community's traditions, values, and norms. Such "purposive memory" shapes a future envisioned by the diaspora leadership—a form of cultural hegemony (González 2016).

\section{A Top-Down Mobilization of the Past}

In 2015, the Aramean, Assyrian, and Chaldean push for recognition reached a climax with the organization of a variety of events commemorating the Sayfo centenary; all Syriac-Orthodox churches were asked to organize commemorations; in several countries the Church dedicated permanent memorials. New alliances with the Armenian community for organizing joint commemorations (the Committee of 1915; art displays in libraries; silent processions) facilitated the engagement of the younger generation.

The Syriac Orthodox Church of Antioch—its patriarchate actually seated in Damascusassumed a leading role. In other genocides, as Jakobovits observes, religious authorities may well be the least eager to confront the theological complexities and existential questions consequent upon events (Jacobovits 1988; Swazo 2018). In the Sayfo campaign, by contrast, the Syriac Orthodox Church assumed a leading role. In 2014 the new patriarch, Mor Ignatius Aphrem II, undertook a clear international political agenda, more than did his predecessor, Mor Ignatius Zakka I. Previous patriarchs had organized commemorations, but behind church doors. Past Syrian and Turkish governments sustained good relations, though complications involving the Kurdish Question that emerged during the international war against the Islamic State of Iraq and Syria (ISIS) have put Presidents Assad and Erdogan at loggerheads, making criticism of the latter from the (relative) safety of Damascus easier. 
The new patriarch oversaw commemorations in the global public domain, raising awareness of persecutions of Christians in the Middle East today more generally. He mobilized the Sayfo strategically to address current community needs: preventing new genocidal violence against Christians. After his inauguration he toured Syriac-Orthodox communities around the world. His letter urging commemorations on the centenary of the Sayfo was read during Mass in Aramaic, Arabic, or English at all Syriac-Orthodox churches around the world. Many urged April 24, the official commemoration date for the Armenian Genocide, but the Synod of the Syriac-Orthodox Church chose June 15, arguing that the two should be kept separate. Parishioners throughout the world were soon organizing symposia, arranging public readings, dedicating monuments_-activities meant to reinforce transnational diasporic identity.

The Patriarch helped design an official logo for the Sayfo, distributing it via the SyriacOrthodox bishops (seven out of forty-one of them in Europe). It has since featured in numerous commemorative publications and events. During the Patriarch's visit to the Netherlands between February 23 and March 3, 2015, parishioners raised banners and lit candles with the new logo in all Syriac Orthodox churches and read the names of all villages and cities that had been struck by the genocide. Metropolitan Aydin explained to us his purposes in organizing the effort in the Netherlands:

\begin{abstract}
I believe that we should ... make sure the Sayfo will not be forgotten. Not only because of the recognition struggle, but also because we should prevent it from ever happening again, towards us or other peoples. Our main goal is to involve the next generations, because it will be up to them to keep the memory alive. We should think about different forms to reach out to younger generations, for example by organizing plays about the Sayfo. This way, the narratives will be kept alive and younger generations will be inspired by their ancestors, both spiritually and heroically [Aydin 2016].
\end{abstract}

The Metropolitan explained that the ecclesiastical hierarchy's narrative addresses current community needs. Apart from preventing new genocides against Christian minorities in the Middle East, and in particular responding to ISIS atrocities against Christians in the Mesopotamian homeland, the Metropolitan suggested that the Sayfo narrative will inspire future generations. The accounts of persecution, dislocation, violence, sacrifice, heroism, and martyrdom bear a religious significance for current and future clergy and laity alike.

The Metropolitan stressed that, absent any government representing the Aramean, Assyrian, and Chaldean communities, the campaign is an international affair that compels the hierarchs to assume political roles: reaching out to governments, creating political alliances, promoting interfaith dialogue, establishing a platform to win popular and official recognition. During his stay, the Patriarch spoke before Parliament in the Netherlands and before the European Parliament in Brussels to discuss the current situation of Christians in Syria and Iraq. In an interview with a Dutch newspaper, the Patriarch reiterated what he had said in front of the two parliaments, namely that Christians in Syria and Iraq feel abandoned by the West (KRO-NCRV 2015). He argued that the interests of Western corporations appeared to governments more important than the blood of persecuted Christians. The Patriarch clearly spoke as representative of the Mesopotamian Christian communities in international affairs. Mor Ignatius Aphrem II sought to advise Western powers in geopolitical affairs, taking on the role of expert on Middle East affairs, pleading for pressure on Saudi Arabia, Turkey, and Qatar. The governments of these three countries, the Patriarch claimed-perhaps controversially—extended assistance to ISIS. Moreover, the Patriarch urged 
Western governments to cooperate with the armed forces of President Bashar al-Assad against ISIS: the Christian minorities had been relatively safe under the Assad regime, but were experiencing brutal persecution under ISIS. For Mor Ignatius Aphrem II, apparently, the Assad regime and ISIS were the only two options left in Syria. In other words, the Patriarch articulated a de facto political alignment with the Assad regime.

Metropolitan Aydin also emphasized the wider international context. The centenary took place against the background of the Syrian Civil War (2011-). ISIS's genocidal campaign against Christians - according to both the patriarch and the Metropolitan-drew upon support from Sunni circles in Saudi-Arabia, Turkey, and Qatar. "Glocal," the 2015 commemorations appealed to local, national, and international audiences to intervene on behalf of Christians in the Middle East. As the Metropolitan explained the situation to us,

\begin{abstract}
there are many stakeholders when it comes to recognition of the Sayfo. Of course [these include] the victimized people who seek recognition and justice for their suffering. However, Turkey plays an important role, because they refuse to recognize the Sayfo. Other countries refuse as well. It is easier to deny the Sayfo and to keep good relations with Turkey than to recognize the truth for a people without a land. If Turkey would recognize [the genocide], it would mean that they have to rewrite their own history and admit to have [sic] lied to their people all those years. It would also mean that compensation would be appropriate, compensation for trauma but also for lost land and properties, like the Jews have received [sic] after the Holocaust.
\end{abstract}

The Metropolitan centered on Turkey's misrepresentation of history as the key obstacle. As long as that government fails to acknowledge the Sayfo, he asserted, the Aramean, Assyrian, and Chaldean peoples - in contrast with the victims of the Holocaust-feel oppressed, denied what is due them. Hence, he was not only using the Sayfo to strengthen a diaspora identity, but also using the past to address an ongoing pattern of Turkish oppression. The campaign, then, is also a postgenocidal struggle for rights-including rights to compensation for stolen property. The struggle, the Metropolitan emphasized, must pursue acknowledgment by other states, do so through a strictly moral appeal, and convince them to pressure Turkey to acknowledge the genocide and the just demand of the Christian minorities for recognition (the secular World Council of Arameans, a nongovernmental NGO, pursues a more nationalistic agenda).

\title{
A Grassroots Mobilization of the Past
}

The ecclesiastical hierarchy may be the key actor inscribing a Sayfo narrative onto the diasporic community's identity, yet that diaspora also sustains a grassroots movement. Local committees have organized remembrances, collective mourning, and other symbolic representations: the Bote Committee is merely one of many. Such groups project their own self-image, even if not fully autonomously from the clergy. Grassroots associations are typically organized around descent. Members share the same Mesopotamian homeland and their ancestors often were born in the same villages. When the Arameans, Assyrians, and Chaldeans emigrated in the 1970s, they organized a kind of transnational connectivity via such committees, often identifying with particular (and usually abandoned) villages. In the Sayfo recognition campaign, committees have organized fundraising for church restorations in the homeland; the preservation of the cultural heritage of towns and districts, even though it is currently impossible to actually live there; and educational, social, and 
commemorational events. We studied the Bote Committee to better appreciate how a campaign could be organized from below, and how grassroots committees might use history in their activities.

The Bote Committee was originally established in 1999 to restore the two churches in the village, plundered and long-neglected by both the local Kurds and the government. One had been converted into a mosque. The Bote Committee embraced one sub-committee in the Netherlands (whose members reside there or in Germany), and another in Sweden. Each group has its own chairperson. Members are all descendants of survivors of the Sayfo, see each other during periodic committee gatherings, and chat via WhatsApp on a weekly basis. The Dutch and Swedish groups communicate on a regular basis. In 2013 Father Abrohom Garis, a Syriac-Orthodox priest in Sweden and himself a descendant of Sayfo survivors from Bote, came up with the idea of a commemoration of the victims. He suggested to the other Committee members that the commemoration should be held in Bote itself, at the Mor Afrem church (the village's other church, Chaldean, was named Yoldath Aloho, Holy Mother of God). Mor Afrem was especially suitable, Father Garis explained two years later (these were only two of his unsuccessful attempts), because: "Mor Afrem played an important role during the Sayfo of Bote. The church was built upon a hill, strategically, so it was the best place to defend ourselves. Before the Sayfo started, some army officers gathered in our village, supposedly to defend us from the Kurds, but the Ottoman government had other plans: they wanted to exterminate all Christians in their territory. So the second our people found out that they would come under attack, they all fled inside the church" (Garis 2015).

Arameans, Assyrians, and Chaldeans alike—some 1,500 people in all-barricaded themselves inside Mor Afrem for thirteen days in July 1915, besieged by Kurdish locals. In Garis's narration, for the last three days these villagers had neither food nor water, and thus no option in the end but to fling open the church doors and fight or flee-few are known to have survived (Garis 2015). The communities in the Netherlands, Germany, and Sweden all know this story. Mor Afrem is the most important site of group memory of the genocide in Bote. A commemoration in the church itself therefore seemed appropriate, at least according to Father Garis. However, other Committee members brought up the danger involved, albeit one hundred years after events. As Zeki Numansen, the son of Bote survivors, recalled his objections to Father Abroham's plan,

the idea [of organizing] the commemoration in Bote is very good; however it scares me. Turkey shows a very clear denial policy when it comes to the Sayfo, and the local Kurds who currently live in Bote are also not pleased with our visits. When I went there to restore the Chaldean church, I noticed their hostility. They were even colder than when we lived there. It seems their hatred has grown, and then there is the whole [ISIS] situation. When ISIS members would hear about Christians coming to commemorate the Sayfo, they would attack immediately and we would all be dead [Numansen 2016].

Fear of attack even in twenty-first-century Turkey motivated the decision to hold the commemoration in Gothenburg rather than onsite-in any case the village of Bote itself remains largely abandoned today. This fear may be compared to that of Armenians contemplating visits to Turkey; according to Balakian (2013), diaspora Armenians not only experience past trauma themselves, but also fear exacerbating the bigotry that the small remaining Armenian population of Turkey still faces, or even provoking physical assaults against it. Netherlands sub-committee chair Yakub Mutlu argued against holding the event in Bote, reporting that the bishop of the Syriac Orthodox monastery in Turkey had urged a European commemoration because an event in Turkey would make resident Arameans, Assyrians, and Chaldeans targets for retaliation. 
Mutlu also noted more mundane reasons for holding the event in Europe: only a handful of people would be able to afford a trip to Turkey, and, more importantly, a majority of those most interested would have been too old. To reach the younger generation, he argued, it would be better to keep things in Europe. Though Mutlu suggested the Netherlands, the Swedish sub-committee offered to host it, and the Netherlanders acquiesced. During our interviews, Committee members told us that the discussions elicited no profound disagreements. Garis of course agreed with alacrity, booked a location, and organized a day-long program for Sunday July 5 . Events started with breakfast and then songs, poetry readings, and a display of photos of the survivors. Garis read from his own book on the Sayfo in Bote (Garis 2017). After his reading he spoke about the subject as well. After this there was a memorial service, followed by dinner and a social evening.

Committee members claim their struggle will not cease until they receive full recognition: not only an apology from the Turkish government, but much more (given the loss of property and life, and the subsequent humiliations). As chairman Mutlu, put it:

\begin{abstract}
We need to tell the world about the Sayfo, but in particular Turkey. Our people were massacred, and more than seventy percent is gone. No one in the entire world cared about us and about the fact that an entire people vanished. If our people would have planted bombs in Turkey, thirty years ago ... the world would have known about the Sayfo. But we didn't act with violence so no one cares. All our land is taken from us, all our property and belongings and all our ancestors slaughtered, if one would calculate our loss it would be in the billions. Once, I heard about a Jewish lady who lived in the USA, but was a descendent of Polish Jews. Her family fled to the U.S. after the Holocaust and many years later she returned to Poland to claim her parent's house. She immediately received the amount of money the house was worth and retroactive payment of rent for all those years that the house was inhabited by others. During the Holocaust all the gold of the Jewish people was stolen and melted down, and after the Holocaust they claimed back all this money. This is what I call democracy, this way Jews can find their peace and make peace with their former oppressors. But not us.... No one cares about our people. From Urhoy (Edessa) to Iraq was once our land, parts of Syria and Lebanon, all taken away from us [Mutlu 2016].
\end{abstract}

Mutlu spoke for many Arameans, Assyrians, and Chaldeans, for whom the struggle for recognition means restitution - both of their wealth and their Mesopotamian homeland. The comparison to the Holocaust and its aftermath entails comparisons too with Jewish experience after the Holocaust. That comparison extends to the Jewish diaspora, but not to the establishment of a state. Anthony Smith (1999) argues that nationalism can be understood as a mix of ethnic identities, cultural bonds, and histories that give shape to national communities; nationalism, he stresses, draws its staying power from modern elites' rediscovery and reinterpretation of cultural myths and symbols. Mutlu articulates nationalist attitudes that indeed reiterate Jews' "rediscovery and reinterpretation of myths and symbols" during their successful achievement of a historical justice, justice still denied but nevertheless owed to the Assyrians, Armenians, and Chaldeans. Some of the imagined successes of the Jews must remain subject to correction and interpretation, of course, but descendants of the Sayfo state them as fact, simultaneously contrasting them to their own experiences and holding them up as a model for their own century-long struggle.

\title{
Using the Media to Mobilize the Past
}

Like comparable struggles today, the Sayfo recognition campaign relies to a large degree on the media (Maia 2014). Members of the ecclesiastical hierarchy, and primarily Patriarch Aphrem II, 
frequently grant interviews to the media when they travel abroad. Local committees use social media to sustain and enhance transnational bonding and to discuss numerous issues of concern. In the Sayfo campaign, no group makes more extensive use of media tools than the World Council of Arameans. The WCA is the most significant political organization of the Arameans, and is the only Aramaic-speaking NGO to enjoy special consultative status with the Economic and Social Council of the UN. This means that the WCA can send delegates to the UN's headquarters in New York and to its offices in Vienna and Geneva (WCA [b] 2016). In 2013 and 2014 WCA chairman Johny Messo approached Dutch Evangelical Television to seek support for a documentary about the Sayfo, originally intended for an international audience but ultimately produced in Dutch without Englishlanguage subtitles. The fifty-two-minute program, Sayfo: A Forgotten Genocide, was broadcast on Dutch television on April 22, 2015 (Evangelische Omroep 2015). The WCA, its local affiliate the Federation of the Arameans in the Netherlands, and four local Aramean associations had organized an exclusive premiere two days earlier in the cinema of Enschede, a city with an Aramean community, on April 20, 2015. Descendants of Sayfo survivors attended (WCA [a] 2015), and the WCA handed out flyers with the message "We survived" for members of the entire audience to hold for a photo subsequently posted online and circulated via social media.

The WCA actively exploited mass media to advance messages, images, and symbols. Messo told us how the documentary was arranged as a strategy for mobilizing the past to further the WCA's recognition campaign:

In 2008, Johan David and I tried to convince the Dutch Evangelical Broadcasting channel (EO) to make a documentary about our people. Although they sympathized ... the EO did not deem it worthy of airtime. As the centenary of the Ottoman Genocide approached, we gave it another try. This time, the Christian channel agreed on the condition that we would share ... production costs, while they would stay in charge of and responsible for the documentary itself. The WCA, its member country federations, the Aramaic satellite channel Suryoyo Sat, and two partners from Sweden who jointly invested in this project accepted these terms, provided that the film should be broadcast before April 24 on Dutch national television and that we would be allowed to translate it and show it in other languages too. Our aim was simply to raise awareness and make people think about the Sayfo against the Arameans a hundred years ago, their plight in the present, and their gloomy future. The world should know, see, and feel that our suffering did not end a century ago, but continues as a result of the silence, indifference, and inaction of the international community [Messo 2016].

The documentary was eventually made, but in fact focused less on the genocide itself than on the recognition campaign. It opened with images of the lost homeland, in the mountainous region of Tur Abdin in southeast Turkey—a mere thirty kilometers from ISIS-controlled areas. It developed several messages: The Arameans are an ancient Mesopotamian people, among the first Christians (Christ spoke Aramaic), with their own rich civilization. More than 70 percent of the Arameans in that part of the world were killed or lost to the local community in 1915 and the following years. The genocide did not consist solely in that, but as well in cultural destruction, the loss of property, and the ruin of cultural heritage sites. The Sayfo has not been well-documented in literature, historical scholarship, or popular media. Memory depends on the survivors, transmission within families; the history of the Sayfo must be reconstructed through eyewitness reports.

During preparation of the documentary the WCA had to identify and meet Arameans scattered in several countries. The documentary presented as well storytelling by the children and grandchildren of Sayfo survivors-a performance of the tragedy that invited viewers into an 
alternative reality based on traumatic events. The precise, painful details of outrage and murder and suffering made descendants into eyewitnesses, illustrating how oral tradition can sustain a culture.

The documentary presents as well the post-genocidal aftermath in authoritarian Turkey, where survivors have enjoyed no possibility of organized mourning: Christian residents of Hah, one of the last Aramean villages there (whence, local tradition has it, the three Magi left for Nazareth), explained to the filmmakers and Johny Messo that it was still not safe for them to speak openly about the Sayfo, fearful of the local Kurdish and Turkish population. Not far from ISIS territory, these villagers considered the Turkish government and ISIS partners in at least one crime: intimidation. For the villagers, the Sayfo narrative continues, for they have every reason to fear another genocidal massacre. Indeed, the filmmakers included the escape of the bishop of Mosul after ISIS's invasion in June 2014 and the following cleansing of the city's Christians. The documentary draws parallels with what is happening to Christian communities throughout much of the Middle East today. In comparison with documentaries about the Armenian Genocide (Markovitz 2006), the Sayfo documentary devotes less attention to the past and more to the present.

The life stories presented by the film bring to light personal experiences of persecution, murder, trauma, and loss_-and advance the WCA's recognition campaign while justifying specific actions such as the establishment of commemoration sites by diasporic communities (prohibited in Turkey itself). Messo contends that the loss of Aramean heritage and language, as well as the loss of villages, churches, monasteries, cemeteries, and other landscapes, justifies the quest for statehood. That quest is a new agenda, inspired in part by current events. It resembles the early Zionist movement. Messo contends that the genocide and the post-genocidal century-leaving only 3,000 Arameans in southeast Turkey-prove that the Arameans can survive as a people only in their own autonomous territory. The WCA translates negative experiences of genocide into future-oriented political organization. Per Smith's conception, it seems clear that despite living in a diaspora and despite successful integration in the West, the Arameans' dream of their own homeland persists.

Gouriévidis $(2014,2)$ argues that the struggle for recognizing the past sustains collective identity through the representation of place. The Sayfo documentary represents one example. Organized remembrance, mourning, and symbolic presentation—voiced through selected spokespersonsconstitutes a transnational Aramean identity anchored in a common trauma and presented to a contemporary world in a context of renewed persecution. The documentary represents the WCA's political program. It connects history to the persecution of Christians in the Middle East today, and specifically the depredations of ISIS forces allegedly encouraged by Turkey (a country in fact supporting the war against ISIS). Messo told us that when the documentary was shown at the UN Offices in Geneva, the Turkish ambassador "was not quite happy." Yet Messo also told us that the WCA seeks reconciliation with Turkey, explaining that it desires diplomatic relations with the government and stressing that cooperation would "help improve Turkey's human rights situation" (Messo 2016).

That Turkey still denies this genocide impacted the filmmakers' work there. Markovitz (2006) explains that when making a film about the Holocaust, directors can assume that most of their audience share a common base of knowledge: collective memory of World War II is widely and firmly entrenched, indeed institutionalized, throughout the West. By contrast, films about Christians in the Ottoman Empire appear in the context of widespread ignorance and an official denialism powerful enough to cloud historical memory. Markovitz claims that the Turkish government has worked successfully enough to discourage public discussion that Hollywood production companies (for 
instance) have shown little interest in depicting these genocides. Despite this, in 2016 Hotel Rwanda director Terry George brought to the big screen a film set during the Armenian Genocide, 2017's The Promise (set during the last days of the Ottoman Empire and following the love triangle between the medical student Michael, the beautiful and sophisticated Ana, and an American journalist). Still, feature films related to the events of 1915 to 1918 are virtually non-existent.

A Forgotten Genocide includes the actual moment when Johny Messo learned via telephone that ISIS has attacked an Aramean village in Syria and murdered as many as 300 defenseless victims. And yet the subtext of the film, powerfully communicated in the simple words of ordinary people, is the fear of cultural loss through the very success of life in the diaspora: uprooting, the relocation of identity, and language loss, especially among younger generations who no longer speak Aramaic in their daily lives.

\section{Concluding Remarks}

In this article we have discussed how Aramean, Assyrian, and Chaldean diasporic communities in the Netherlands, Germany, and Sweden mobilize their shared Sayfo past and the memory of repression in authoritarian Turkey to organize a multi-pronged struggle for recognition. We selected three examples from 2015 to analyze how communities used the past in their campaign. The efforts of the Syriac-Orthodox Church of Antioch, the Bote Committee, and the World Council of Arameans show how they employed the Sayfo to sustain a collective identity among Sayfo descendants, a sense of diasporic belonging, and a relationship to the lost homeland. Still, we observed that the three stakeholders used the past differently.

The Syriac-Orthodox Church uses a narrative of what happened in 1915 and the following years in a top-down management strategy to unify the diaspora against worldwide ignorance of the Sayfo, to gain global recognition, and to combat worldwide silence over the continuing persecution of Christians in the Middle East.

The Bote Committee, on the other hand, remains a grassroots association of descendants of families who once lived in northwestern Mesopotamia, working to sustain the memory and cultural heritage of a lost homeland — or rather one small but emblematic village. Its highly specific narrative focuses not only on one place, but on one month; its commemorations mention by name the hundreds of individuals who experienced genocidal massacre during one component event in the Sayfo.

The World Council of Arameans represents a global, but secular agency. Its use of the past, however, differs from that of the Syriac-Orthodox Church (even though they often cooperate). In contrast with the Church and the Bote Committee, the WCA is not itself a world or a local community, but rather an NGO. It works toward recognition via diplomatic channels, by lobbying within the UN, and by providing information to the media. Its employment of the past relies strongly on the letter, as its documentary for Dutch television illustrates. Both grassroots and hierarchical, the WCA mobilizes history in pursuit of the dream of an Aramean state, something that would require recognition by the international community.

The sermons of the persecuted bishop of Mosul, the interviews of Patriarch Aphrem II, the story-telling and book readings of father Abroham Garis of the Bote sub-committee in Sweden, the WCA documentary, and the central role in the latter of Johny Messo-all of these narratives enable audiences to revisit the Sayfo. Both the top-down and bottom-up organization of the struggle, and the manner in which various stakeholders presented the past during the centenary commemorations, 
manifested specific peculiarities if only because organization involves management, hierarchy, and control. The consequent ambiguity does not find expression in the accounts of Taylor or Honneth; yet such ambiguity should be central if we want to understand how educational efforts may strategically employ the past. All efforts remain ambiguous because they involve ideology (typically nationalism), organization, decision-making, management, political tactics, rhetoric, ecclesiastical hierarchy, and control over diasporic identity. Remembering, mourning, and representing the past meet present community needs and further community political goals: if not Aramean statehood (say), then at least the improvement of the human rights regime in Turkey today and the protection of the surviving Aramean minority (as envisioned by the WCA leadership).

What we did not encounter, however, was contestation of today's varied leadership. By the same token, we did not find contestation among leaders' and activists' representations of the Sayfo or its strategic uses. These all could have become arenas for political debate, at least within the Aramean, Assyrian, and Chaldean communities. Fortunately, the debate is with the outside world, not within their own inner world.

Sofia Mutlu-Numansen is a Ph.D. candidate at the University of Twente. She published two articles in 2015 about the genocide of Arameans/Assyrians/Chaldeans in the Ottoman Empire: "Patterns of migrant post-memory: The politics of remembering the Sayfo"; and "Heroines of gendercide: The religious sensemaking of rape and abduction in Aramean, Assyrian, and Chaldean migrant communities."

Marinus Ossewaarde is associate professor in sociology of governance at the University of Twente, the Netherlands. He is the author of Tocqueville's Moral and Political Thought: New Liberalism (London: Routledge, 2004); and Theorizing European Societies (Basingstoke, UK: Palgrave Macmillan, 2013). He has published a variety of articles on topics like Europe, cultural movements, sovereignty, cosmopolitanism, memory, identity, publics, dialectics, and self-responsibility in journals like Current Sociology, Critical Sociology, The European Journal of Social Theory, The Canadian Journal of Sociology, European Societies, Sociology, and The European Legacy.

\section{References}

Allen, Matthew, and Steven D. Brown, "Memorial Meshwork: The Making of the Commemorative Space of the Hyde Park 7/7 Memorial,” Organization 23, no 1 (2016): 10-28.

Atman, Sabri, speech on the $2^{\text {nd }}$ Annual Hellenic Genocide Commemoration, Seyfo Center in New York, http://www.seyfocenter.com/?sid=2\&aID=201 (accessed March 10, 2016; last modified October 4, 2010).

Aydin, Metropolitan Mor Polycarpus Augin, interview, February 23, 2016.

Balakian, Peter, "Raphael Lemkin, Cultural Destruction, and the Armenian Genocide," Holocaust and Genocide Studies 27, no. 1 (2013): 57-89.

Bowring, Bill, “Austro-Marxism's Last Laugh? The Struggle for Recognition of National-Cultural Autonomy," Europe-Asia Studies 54, no. 2 (2002): 229-50.

“Comité 1915," http://comite1915.blogspot.nl/ (accessed October 22, 2019).

Cutcher, Leanne, et al. "Spaces and Places of Remembering and Commemoration," Organization 23, no. 1 (2016): 3-9.

de Courtois, Sébastien, The Forgotten Genocide: Eastern Christians, the Last Arameans (Piscataway, NJ: Gorgias Press, 2004. 
Dixon, Jennifer M., "Defending the Nation? Maintaining Turkey's Narrative of the Armenian Genocide," South European Society and Politics 15, no. 3 (2010): 467-85.

Elgenius, Gabriella, "The Politics of Recognition: Symbols, Nation Building and Rival Nationalisms," Nations and Nationalism 17, no. 2 (2011): 396-418.

Evangelische Omroep, “Sayfo, De Vergeten Genocide," http://www.2doc.nl/documentaires/series/2doc/2015/ april/sayfo-de-vergeten-genocide.html (accessed October 22, 2019).

Gabriel, Yiannis, "Organizations in a State of Darkness: Towards a Theory of Organizational Miasma," Organization Studies 33, no. 9 (2012): 1137-52.

Galip, Özlem, "The Politics of Remembering: Representation of the Armenian Genocide in Kurdish Novels," Holocaust and Genocide Studies 30, no. 3 (2016): 458-87.

Garis, A., Bote 13 Günlïk Cehennem Süryani Köyünde 1915 Mezalimi (Istanbul: Belge Yayınlan, 2017).

Garis, Abrohom, commemoration lecture in Bockaberg about the Sayfo in Bote, July 4, 2015.

Gaunt, David, Massacres, Resistance, Protectors: Muslim-Christian Relations in Eastern Anatolia During World War I (Piscataway, NY: Gorgias Press, 2006).

Gaunt, David, Naures Atto, and Soner O. Barthoma, eds., Let Them Not Return. Sayfo-The Genocide against the Assyrian, Syriac, and Chaldean Christians in the Ottoman Empire (Oxford, UK: Berghahn Books, 2017).

Gingeras, Ryan, review of David Gaunt, Massacres, Resistance, Protectors. Muslim-Christian Relations in Eastern Anatolia during World War I; and Arnold Reisman, Turkey's Modernization: Refugees from Nazism and Atatürk's Vision, Holocaust and Genocide Studies 22, no. 3 (2008): 539-43.

González, Pablo A., "The Organization of Commemorative Space in Postcolonial Cuba: From Civic Square to Square of the Revolution," Organization 23, no. 1 (2016): 47-70.

Gouriévidis, Laurence, Museums and Migration: History, Memory and Politics (London: Routledge, 2014).

Honneth, Axel. The Struggle for Recognition: The Moral Grammar of Social Conflicts (Cambridge, UK: Polity Press, 1995).

Jakobovits, Immanuel, "Faith, Ethics and the Holocaust: Some Personal Theological and Religious Responses to the Holocaust," Holocaust and Genocide Studies 3, no. 4 (1988): 371-81.

Kleist, Nauja, "In the Name of Diaspora: Between Struggles for Recognition and Political Aspirations," Journal of Ethnic and Migration Studies 34, no. 7 (2008): 1127-43.

KRO-NCRV, "Mor Ignatius Aphrem II in Amsterdam," http://www.kro-ncrv.nl/inspiratie/nieuws/370-33926mor-ignatius-aphrem-ii-in-amsterdam (accessed May 10, 2016).

Levene, Mark, "Creating a Modern 'Zone of Genocide': The Impact of Nation- and State-Formation on Eastern Anatolia, 1878-1923," Holocaust and Genocide Studies 12, no. 3 (1998): 393-433.

MacNay, Lois, "The Trouble with Recognition: Subjectivity, Suffering, and Agency," Sociological Theory 26, no. 3 (2008): 271-96.

MacQueen, Paddy, Subjectivity, Gender and the Struggle for Recognition (Basingstoke, UK: Palgrave Macmillan, 2015).

Maia, Rousiley C.M., Recognition and the Media (Basingstoke, UK: Palgrave Macmillan, 2014).

Markovitz, Jonathan, "Ararat and Collective Memories of the Armenian Genocide," Holocaust and Genocide Studies 20, no. 2 (2006): 235-55.

Meisiek, Stefan, "Which Catharsis Do They Mean? Aristotle, Moreno, Boal and Organization Theatre," Organization Studies 25, no. 5 (2004): 797-816.

Melson, Robert, "Recent Developments in the Study of the Armenian Genocide," Holocaust and Genocide Studies 27, no. 2 (2013): 313-21. 
Messo, Jonny, interview, May 19, 2016.

Moore, Rebekah, "A Crime Against Humanity Arguably Without Parallel in European History: Genocide and the 'Politics' of Victimhood in Western Narratives of the Ukrainian Holodomor," Australian Journal of Politics and History 58, no. 3 (2012): 367-79.

Morris, Benny, and Dror Ze'evi, The Thirty-Year Genocide: Turkey's Destruction of Its Christian Minorities, 1894-1924 (Cambridge, MA: Harvard University Press, 2019), 198, 202, 203, 374-80.

Moses, Dirk, "Does the Holocaust Reveal or Conceal Other Genocides? The Canadian Museum of Human Rights and Grievable Suffering," in Hidden Genocides: Power, Knowledge, and Memory, ed. Doug Irvin, Alexander Hinton, and Tom LaPointe (New Brunswick, NJ: Rutgers University Press, 2013), 21-51.

Mutlu, Yakub, interview, March 23, 2016.

Numansen, Zeki, interview, January 11, 2016.

Önder, Söner, "Minority Rights in Turkey: Quo Vadis, Assyrians?," in Pieter Omtzigt, Markus Tozman, and Andrea Tyndall, The Slow Disappearance of the Syriacs from Turkey: And of the Grounds of the Mor Gabriel Monastery (Münster, Germany: LIT Verlag, 2012).

Özlem Biner, Z. "Multiple Imaginations of the State: Understanding a Mobile Conflict about Justice and Accountability from the Perspective of Assyrian-Syriac Communities," Citizenship Studies 15, no. 3-4 (2011): 367-79.

Omtzigt, Pieter, Markus Tozman, and Andrea Tyndall, The Slow Disappearance of the Syriacs from Turkey: And of the Grounds of the Mor Gabriel Monastery (Münster, Germany: LIT Verlag, 2012).

Presbey, Gail M. "The Struggle for Recognition in the Philosophy of Axel Honneth, Applied to the Current South African Situation and its Call for an African Renaissance," Philosophy and Social Criticism 29, no. 5 (2003): 537-61.

Robben, Antonius C.G.M., "From Dirty War to Genocide: Argentina's Resistance to National Reconciliation," Memory Studies 5, no. 3 (2012): 305-15.

Rowlinson, Michael et al. "Social Remembering and Organizational Memory," Organization Studies 31, no. 1 (2010): 69-87.

Savage, Roger W.H., "Crisis, Conflict, and the Struggle for Recognition," Philosophy Today 57, no. 1 (2013): $72-83$.

Short, Damien, "When Sorry Isn't Good Enough: Official Remembrance and Reconciliation in Australia," Memory Studies 5, no. 3 (2012): 293-304.

Smith, Anthony D., Myths and Memories of the Nation (Oxford: Oxford University Press, 1999).

Sørensen, Bent Meier, "Changing the Memory of Suffering: An Organizational Aesthetics of the Dark Side," Organization Studies 35, no. 2 (2014): 279-302.

Swazo, Norman Kenneth. "Questioning Islamic Belief in Post-Genocide Bangladesh: Mu'tazalites and Ash'arites, May and Sohail.” Holocaust and Genocide Studies 32, no. 2 (2018): 272-90.

Taylor, Charles, Multiculturalism and the Politics of Recognition (Princeton, NJ: Princeton University Press, 1992).

Thompson, Janna, "Apology, Historical Obligations and the Ethics of Memory," Memory Studies 2, no. 2 (2009): 195-210.

Üngör, Uğur Ümit. "Lost in Commemoration: The Armenian Genocide in Memory and Identity." Patterns of Prejudice 48, no. 2 (2014): 147-66.

WCA(a), "Sayfo: a Forgotten Genocide' premières in the Netherlands," http://www.wca-ngo.org/sayfo/538sayfo-a-forgotten-genocide-premi\%C3\%A8res-in-the-netherlands (accessed October 22, 2019). 
WCA(b), "The World Council of Arameans (Syriacs) ('WCA')," http://www.wca-ngo.org/about-us/wca (accessed October 22, 2019).

WCA(c), "The Indigenous Origins of the Arameans of Upper Mesopotamia," http://www.wcango.org/ heritage/247-the-indigenous-origins-of-the-arameans-of-upper-mesopotamia (accessed April, 19, 2017).

Westwood, Robert, "Comic Relief: Subversion and Catharsis in Organizational Comedic Theatre," Organization Studies 25, no. 5 (2004): 775-95.

Young, James, The Texture of Memory: Holocaust Memorials and Meaning (New Haven, CT: Yale University Press, 1993).

Zhurzhenko, Tatiana, “Capital of Despair," East European Politics and Societies 25, no. 3 (2011): 597-639. 